\title{
Growth Response of Three Leafy Vegetables to the Allelopathic Effect of Vitellaria paradoxa
}

\author{
Olamide O. FOLARIN ${ }^{1 *}$, Clement O. OGUNKUNLE ${ }^{1}$, Stephen O. OYEDEJI ${ }^{1}$, \\ Saheed KOLAWOLE ${ }^{2}$ \\ IUniversity of Ilorin,Faculty ofLife Science, Department of Plant Biology, PMB 1515, Ilorin, Nigeria;folarinmide@gmail.com ("correspondingauthor), \\ seyeogunkunle@gmail.com;princeseyedlst@yahoo.com \\ ${ }^{2}$ Federal University of Kasere, Faculty of Science, Department of Biological Science, PMB0182, Gombe, Nigeria
}

\begin{abstract}
This study was conducted to evaluate the growth response of three leafy vegetables (Celosia argentea, Amaranthus cruentus and Amaranthus hypochodriacus) to the leaf extract of Vitellaria paradoxa. Forty-five (45) experimental plastic containers were filled with $5 \mathrm{~kg}$ of loamy soil each and randomly allocated to the following regimes: control, $20 \mathrm{~g}, 40 \mathrm{~g}, 60 \mathrm{~g}$ and $80 \mathrm{~g}$ of powdered leaves of $V$.paradoxa, in three (3) replicates for each test crop respectively. It was observed that the response of the three leafy vegetables, grown within different composition of $V$.paradoxa leaves, are concentration dependent with respect to the studied growth parameters (plant height, leaf number, leaf area, stem girth). This indicated that $V$. paradoxa has allelopathic potential on the studied vegetables and therefore it could be used for natural weed control.
\end{abstract}

Keywords: allelopathy, Amaranthus cruentus, Amaranthus hypochodriacu, Celosia argentea, growth parameters, Vitellaria paradoxa, weed control

\section{Introduction}

Allelopathy is an interference mechanism that inhibits or stimulates the associated plant growth due to a release of chemical substances from live or lifeless plant materials (Harper, 1977; May and Ash, 1990). Allelopathy may also play an eminent role in intraspecific and interspecific competition and may determine the type of interspecific association. The inhibition of one plant by another through the release of allelochemicals is well documented (Alagesaboopathi, 2011). The detrimental effects of allelochemicals on recipient plants are considered to be biotic stress, called "allelochemical stress" (CruzOrtega, 2002).

Effects of leachates from plants, plant extracts and decomposing plant residues have been the focus of several investigators concerned with the role of allelopathy in agriculture. Plant residues often contain a variety of toxins that are known inhibitors of seed germination or seedling growth. Leachates from plants have been proved to suppress seed germination and vegetative propagules, as well as early seedling growth (Dhwan and Gupta, 1996; Babu and Kandasanmy, 1997) and decrease radical growth.

Vitellaria is a light demanding, slow growing tree, with a thick and fissured bark. Shea nut "butter" has many uses and may or may not be refined. Shea butter is mostly used for cosmetics. Throughout Africa, it is used extensively for food and medicinal purposes and is a major source of dietary fat (Maranz et. al., 2004).

The need to reduce harmful environmental effects from the overuse of herbicides has encouraged the development of weed management systems which are dependent on ecological manipulations rather than agrochemicals (Liebman and Ohno, 1997; Zoheir et al., 2008; Ashrafi et al., 2009). However, few studies were conducted on the leaf extract of Vitellaria paradoxa.

The aim of this study was to investigate the allelopathic effect of Vitellaria paradoxa leafs on the growth of Celosia argentea, Amaranthus cruentus and Amaranthus hypochodriacus.

\section{Materials and Methods}

This study was conducted in screen house conditions, within the Department of Plant Biology, University of Ilorin, (N 08 $28^{\prime}$ 53.3", E 04' 40' 28.9"), in the Southern Guinea Savanna belt of Nigeria. The annual rainfall in the area is about $1,200 \mathrm{~mm}$ and temperature varies between $33{ }^{\circ} \mathrm{C}$ and $34^{\circ} \mathrm{C}$ during the year, with a distinct dry season from December to March.

Leaves of Vitellaria paradoxa Linn. were collected from matured tree stands in the University campus, while viable seeds of the three test crops (Celosia argentea, Amaranthus cruentus and Amaranthus hypochodriacus) were obtained from the State 
Ministry of Agriculture, Ilorin, North-central Nigeria.

Fresh samples of Vitellaria paradoxa leaves were cut into small pieces, air dried at room temperature and made into powder using an electric blender. Four different regimes ( $20 \mathrm{~g}, 40$ $\mathrm{g}, 60 \mathrm{~g}$ and $80 \mathrm{~g}$ ) of the powdered leaves were prepared as treatments. Forty-five (45) experimental plastic containers were filled with $5 \mathrm{~kg}$ of loamy soil each and randomly allocated to the following regimes: control, $20 \mathrm{~g}, 40 \mathrm{~g}, 60 \mathrm{~g}$ and $80 \mathrm{~g}$ of powdered leaves, in three replicates for each test crop respectively. The soil in the experimental plastic containers was moisture to saturation with borehole water and left for thorough agglomeration of the powdered leaves with the soil matrices for three days. Few seeds of each test crop of Celosia argentea and Amaranthus sp. were germinated in a nursery and after two weeks, three young seedlings of the same height and vigour of each test crop were transplanted into the plastic containers.

The experiment was set-up for two months with regular irrigation with borehole water in ambient condition of photoperiodism. Measurements were taken two (2) weeks after transplanting (WAT) and lasted for eight (8) weeks with an interval of two weeks. The morphological parameters scored include: plant height, leaf length and breadth, stem girth and leaf number; the plant height, leaf length and breadth were measured with a standard meter rule, while the stem girth was measured with an Electronic Digital
Caliper (Titan 23175 model). The leaf area was calculated according to Pearcy et al. (1989) as follows:

Leaf area $=(\mathrm{L} \times \mathrm{B}) \times \mathrm{K}$

where $\mathrm{L}=$ length of leaf, $\mathrm{B}=$ maximum width and $\mathrm{K}=0.72$

\section{Statisticalanalysis}

Data generated were analyzed using Statistical Package for Social Science (SPSS) 16.0 for Windows. Duncan Multiple Range Test (DMRT) was used to separate mean differences at $\mathrm{p}<0.05$.

\section{Results and Discussion}

Generally, the results revealed that the response of the three leafy vegetables (Celosia argentea, Amaranthus bybridus and Amanranthus hypochondriacus) grown within different levels of leaves' composition of Vitellaria paradoxa are concentration dependent. Statistically, there were significant differences between treatments. The results revealed that the growth parameters of the vegetables decreased with increasing concentration of Vitellaria paradoxa leafs. Consequently, the results indicated that the leaf allelopathy effect of Vitellaria paradoxa significantly inhibited the growth of the studied vegetables. This trend is in line with Jadhar and Gayanar report

Table 1. Mean plant height of the studied leafy vegetables to the allelopathic effect of Vitellaria parodoxa leafs

\begin{tabular}{|c|c|c|c|c|c|}
\hline Specie & Treatment & $2 \mathrm{WAT}$ & 4 WAT & $6 \mathrm{WAT}$ & 8 WAT \\
\hline \multirow{5}{*}{ Celosia argentea } & Control & $8.47 \pm 0.52^{\mathrm{a}}$ & $25.53 \pm 1.74^{a}$ & $42.00 \pm 2.97^{\mathrm{a}}$ & $68.18 \pm 1.80^{\mathrm{a}}$ \\
\hline & $20 \mathrm{~g}$ & $7.00 \pm 1.49^{b}$ & $18.90 \pm 3.40^{\mathrm{b}}$ & $30.80 \pm 2.57^{\mathrm{b}}$ & $48.00 \pm 1.94^{\mathrm{b}}$ \\
\hline & $40 \mathrm{~g}$ & $6.07 \pm 0.79^{b}$ & $11.70 \pm 2.00^{c}$ & $17.33 \pm 2.30^{c}$ & $25.78 \pm 0.76^{c}$ \\
\hline & $60 \mathrm{~g}$ & $4.45 \pm 1.22^{c}$ & $9.45 \pm 1.45^{\mathrm{c}}$ & $14.45 \pm 1.71^{\mathrm{c}}$ & $21.95 \pm 2.59^{c}$ \\
\hline & $80 \mathrm{~g}$ & $3.72 \pm 0.75^{c}$ & $7.32 \pm 1.85^{c}$ & $10.92 \pm 2.95^{c}$ & $16.32 \pm 0.12^{c}$ \\
\hline \multirow{5}{*}{ Amaranthus cruentus } & Control & $8.32 \pm 0.22^{\mathrm{a}}$ & $19.43 \pm 1.91^{\mathrm{a}}$ & $31.27 \pm 2.60^{a}$ & $43.18 \pm 2.06^{a}$ \\
\hline & $20 \mathrm{~g}$ & $8.18 \pm 0.17^{a}$ & $17.75 \pm 2.29^{\mathrm{a}}$ & $28.28 \pm 3.21^{\mathrm{ab}}$ & $38.05 \pm 1.89^{\mathrm{ab}}$ \\
\hline & $40 \mathrm{~g}$ & $7.00 \pm 1.01^{\mathrm{b}}$ & $14.68 \pm 3.31^{b}$ & $23.33 \pm 1.18^{\mathrm{bc}}$ & $31.80 \pm 2.45^{b c}$ \\
\hline & $60 \mathrm{~g}$ & $5.83 \pm 1.68^{c}$ & $12.03 \pm 2.89^{b}$ & $19.46 \pm 1.83^{c}$ & $27.18 \pm 0.89^{c}$ \\
\hline & $80 \mathrm{~g}$ & $3.18 \pm 0.74^{\mathrm{d}}$ & $6.68 \pm 1.21^{c}$ & $10.42 \pm 1.69^{\mathrm{d}}$ & $14.20 \pm 2.42^{\mathrm{d}}$ \\
\hline \multirow{5}{*}{ Amaranthus hypochondriacus } & Control & $8.50 \pm 0.45^{a}$ & $16.97 \pm 2.59^{\mathrm{a}}$ & $25.30 \pm 1.63^{a}$ & $33.80 \pm 1.89^{\mathrm{b}}$ \\
\hline & $20 \mathrm{~g}$ & $8.05 \pm 0.56^{a}$ & $18.72 \pm 2.59^{\mathrm{a}}$ & $29.38 \pm 0.21^{\mathrm{a}}$ & $40.05 \pm 1.85^{\mathrm{a}}$ \\
\hline & $40 \mathrm{~g}$ & $6.83 \pm 0.68^{b}$ & $15.73 \pm 1.42^{\mathrm{a}}$ & $25.30 \pm 2.33^{\mathrm{a}}$ & $34.98 \pm 0.48^{b}$ \\
\hline & $60 \mathrm{~g}$ & $6.08 \pm 0.74^{c}$ & $11.33 \pm 0.92^{\mathrm{b}}$ & $22.17 \pm 1.96^{\mathrm{ab}}$ & $29.03 \pm 2.89^{c}$ \\
\hline & $80 \mathrm{~g}$ & $4.25 \pm 0.52^{\mathrm{d}}$ & $8.35 \pm 1.25^{\mathrm{b}}$ & $12.40 \pm 2.15^{\mathrm{b}}$ & $16.98 \pm 1.42^{\mathrm{d}}$ \\
\hline
\end{tabular}

Means within the column followed by the same letters are not significantly different at $\mathrm{p}<0.05$.

Table 2. Mean leaf number of the studied leafy vegetables to the allelopathic effect of Vitellaria parodoxa leafs

\begin{tabular}{|c|c|c|c|c|c|}
\hline Specie & Treatment & $2 \mathrm{WAT}$ & $4 \mathrm{WAT}$ & $6 \mathrm{WAT}$ & $8 \mathrm{WAT}$ \\
\hline \multirow{5}{*}{ Celosia argentea } & Control & $7.00 \pm 0.63^{\mathrm{a}}$ & $13.00 \pm 0.63^{\mathrm{a}}$ & $21.00 \pm 0.63^{\mathrm{a}}$ & $32.5 \pm 1.05^{\mathrm{a}}$ \\
\hline & $20 \mathrm{~g}$ & $6.33 \pm 1.10^{\mathrm{ab}}$ & $12.33 \pm 1.03^{\mathrm{a}}$ & $18.67 \pm 1.03^{\mathrm{b}}$ & $29.67 \pm 1.50^{\mathrm{b}}$ \\
\hline & $40 \mathrm{~g}$ & $5.83 \pm 0.75^{b}$ & $9.83 \pm 0.75^{\mathrm{b}}$ & $14.83 \pm 1.17^{\mathrm{c}}$ & $23.00 \pm 1.41^{\mathrm{c}}$ \\
\hline & $60 \mathrm{~g}$ & $4.47 \pm 0.82^{c}$ & $7.50 \pm 1.76^{c}$ & $11.50 \pm 1.16^{\mathrm{d}}$ & $19.00 \pm 2.10^{\mathrm{d}}$ \\
\hline & $80 \mathrm{~g}$ & $4.17 \pm 0.41^{c}$ & $6.33 \pm 0.82^{c}$ & $10.17 \pm 0.98^{\mathrm{d}}$ & $16.67 \pm 1.21^{\mathrm{e}}$ \\
\hline \multirow{5}{*}{ Amaranthus cruentus } & Control & $5.00 \pm 0.00^{\mathrm{a}}$ & $10.00 \pm 0.00^{\mathrm{a}}$ & $16.00 \pm 0.63^{a}$ & $21.83 \pm 1.47^{\mathrm{a}}$ \\
\hline & $20 \mathrm{~g}$ & $4.67 \pm 0.52^{\mathrm{ab}}$ & $10.00 \pm 0.89 a$ & $16.33 \pm 1.21 \mathrm{a}$ & $21.33 \pm 1.21^{\mathrm{a}}$ \\
\hline & $40 \mathrm{~g}$ & $4.50 \pm 0.55^{b}$ & $9.17 \pm 1.17^{\mathrm{a}}$ & $13.67 \pm 2.16^{\mathrm{b}}$ & $18.67 \pm 2.73^{b}$ \\
\hline & $60 \mathrm{~g}$ & $4.00 \pm 0.00^{c}$ & $7.00 \pm 1.10^{\mathrm{b}}$ & $10.83 \pm 2.32^{c}$ & $13.83 \pm 1.25^{c}$ \\
\hline & $80 \mathrm{~g}$ & $4.00 \pm 0.00^{c}$ & $6.00 \pm 0.63^{\mathrm{b}}$ & $7.83 \pm 0.75^{\mathrm{d}}$ & $9.83 \pm 0.75^{d}$ \\
\hline \multirow{5}{*}{ Amaranthu shypochondriacus } & Control & $6.30 \pm 0.52^{\mathrm{a}}$ & $13.50 \pm 0.55^{a}$ & $18.50 \pm 0.55^{a}$ & $25.50 \pm 0.55^{a}$ \\
\hline & $20 \mathrm{~g}$ & $6.00 \pm 0.00^{\mathrm{a}}$ & $12.00 \pm 1.27^{\mathrm{b}}$ & $16.83 \pm 1.33^{\mathrm{b}}$ & $22.83 \pm 0.82^{a}$ \\
\hline & $40 \mathrm{~g}$ & $5.50 \pm 0.00^{\mathrm{b}}$ & $8.67 \pm 0.83^{c}$ & $12.67 \pm 0.82^{\mathrm{c}}$ & $17.67 \pm 0.82^{b}$ \\
\hline & $60 \mathrm{~g}$ & $5.50 \pm 0.55^{b}$ & $7.67 \pm 0.52^{\mathrm{d}}$ & $11.67 \pm 0.52^{\mathrm{d}}$ & $15.67 \pm 0.52^{c}$ \\
\hline & $80 \mathrm{~g}$ & $4.67 \pm 0.52^{c}$ & $6.00 \pm 0.00^{\mathrm{e}}$ & $9.00 \pm 0.00^{\mathrm{e}}$ & $12.50 \pm 0.55^{\mathrm{d}}$ \\
\hline
\end{tabular}

Means within the column followed by the same letters are not significantly different at $\mathrm{p}<0.05$. 
Table 3. Mean leaf area of the studied leafy vegetables to the allelopathic effect of Vitellaria parodoxa leafs

\begin{tabular}{|c|c|c|c|c|c|}
\hline Specie & Treatment & 2 WAT & $4 \mathrm{WAT}$ & $6 \mathrm{WAT}$ & $8 \mathrm{WAT}$ \\
\hline \multirow{5}{*}{ Celosia argentea } & Control & $1.18 \pm 0.21^{\mathrm{a}}$ & $4.59 \pm 0.34^{a}$ & $8.26 \pm 0.22^{\mathrm{a}}$ & $16.97 \pm 0.55^{\mathrm{a}}$ \\
\hline & $20 \mathrm{~g}$ & $0.67 \pm 0.17^{\mathrm{b}}$ & $2.64 \pm 0.36^{\mathrm{b}}$ & $5.89 \pm 0.53^{\mathrm{b}}$ & $10.01 \pm 0.76^{\mathrm{b}}$ \\
\hline & $40 \mathrm{~g}$ & $0.52 \pm 0.10^{\mathrm{bc}}$ & $1.68 \pm 1.30^{c}$ & $3.68 \pm 0.10^{c}$ & $5.78 \pm 0.34^{c}$ \\
\hline & $60 \mathrm{~g}$ & $0.43 \pm 0.07^{c}$ & $1.08 \pm 0.71^{\mathrm{d}}$ & $1.50 \pm 0.50^{\mathrm{d}}$ & $2.84 \pm 0.23^{\mathrm{d}}$ \\
\hline & $80 \mathrm{~g}$ & $0.25 \pm 0.06^{\mathrm{d}}$ & $0.70 \pm 0.10^{\mathrm{d}}$ & $0.98 \pm 0.02^{\mathrm{e}}$ & $2.20 \pm 0.24^{\mathrm{e}}$ \\
\hline \multirow{5}{*}{ Amaranthus cruentus } & Control & $0.64 \pm 0.34^{a}$ & $3.30 \pm 0.74^{\mathrm{a}}$ & $9.77 \pm 1.91^{\mathrm{a}}$ & $15.30 \pm 2.40^{\mathrm{a}}$ \\
\hline & $20 \mathrm{~g}$ & $0.75 \pm 0.44^{\mathrm{a}}$ & $4.19 \pm 1.71^{\mathrm{a}}$ & $12.76 \pm 2.51^{\mathrm{a}}$ & $19.83 \pm 2.00^{a}$ \\
\hline & $40 \mathrm{~g}$ & $0.43 \pm 0.13^{\mathrm{ab}}$ & $3.18 \pm 1.31^{\mathrm{a}}$ & $9.78 \pm 2.01^{\mathrm{a}}$ & $15.09 \pm 0.41^{\mathrm{a}}$ \\
\hline & $60 \mathrm{~g}$ & $0.42 \pm 0.18^{\mathrm{ab}}$ & $2.88 \pm 1.75^{\mathrm{a}}$ & $8.97 \pm 1.64^{\mathrm{a}}$ & $14.02 \pm 0.63^{\mathrm{a}}$ \\
\hline & $80 \mathrm{~g}$ & $0.10 \pm 0.06 b$ & $0.52 \pm 0.23 a$ & $1.63 \pm 0.66 b$ & $2.99 \pm 1.35^{\mathrm{b}}$ \\
\hline \multirow{5}{*}{ Amaranthus hypochondriacus } & Control & $2.59 \pm 0.62^{\mathrm{a}}$ & $7.41 \pm 2.29^{\mathrm{a}}$ & $14.42 \pm 3.17^{\mathrm{a}}$ & $27.70 \pm 1.23^{\mathrm{a}}$ \\
\hline & $20 \mathrm{~g}$ & $5.57 \pm 0.88^{a}$ & $6.22 \pm 1.19^{\mathrm{a}}$ & $11.83 \pm 1.30^{\mathrm{b}}$ & $20.96 \pm 0.49^{\mathrm{a}}$ \\
\hline & $40 \mathrm{~g}$ & $0.84 \pm 0.54^{\mathrm{b}}$ & $3.20 \pm 0.90^{\mathrm{b}}$ & $6.14 \pm 1.23^{c}$ & $10.33 \pm 1.89^{\mathrm{a}}$ \\
\hline & $60 \mathrm{~g}$ & $0.50 \pm 0.09^{\mathrm{b}}$ & $2.01 \pm 0.34^{\mathrm{b}}$ & $5.24 \pm 0.34^{\mathrm{cd}}$ & $8.37 \pm 0.54^{\mathrm{a}}$ \\
\hline & $80 \mathrm{~g}$ & $0.32 \pm 0.08^{\mathrm{b}}$ & $1.68 \pm 0.45^{\mathrm{b}}$ & $3.87 \pm 0.77^{\mathrm{d}}$ & $5.53 \pm 0.83^{b}$ \\
\hline
\end{tabular}

Means within the column followed by the same letters are not significantly different at $\mathrm{p}<0.05$.

Table 4. Mean stem girth of the studied leafy vegetables to the allelopathic effect of Vitellaria parodoxa leafs

\begin{tabular}{|c|c|c|c|c|c|}
\hline Specie & Treatment & $2 \mathrm{WAT}$ & 4 WAT & 6 WAT & 8 WAT \\
\hline \multirow{5}{*}{ Celosia argentea } & Control & $0.84 \pm 0.07^{\mathrm{a}}$ & $1.54 \pm 0.70^{\mathrm{a}}$ & $2.14 \pm 0.07^{a}$ & $2.74 \pm 0.07^{\mathrm{a}}$ \\
\hline & $20 \mathrm{~g}$ & $0.63 \pm 0.07^{\mathrm{b}}$ & $1.12 \pm 0.08^{\mathrm{b}}$ & $1.52 \pm 0.08^{\mathrm{b}}$ & $1.92 \pm 0.08^{b}$ \\
\hline & $40 \mathrm{~g}$ & $0.56 \pm 0.05^{\mathrm{b}}$ & $0.84 \pm 0.60^{c}$ & $1.04 \pm 0.06^{\mathrm{c}}$ & $1.64 \pm 0.06^{c}$ \\
\hline & $60 \mathrm{~g}$ & $0.38 \pm 0.10^{c}$ & $0.48 \pm 0.10^{\mathrm{d}}$ & $0.88 \pm 0.10^{\mathrm{d}}$ & $1.28 \pm 0.10^{\mathrm{d}}$ \\
\hline & $80 \mathrm{~g}$ & $0.84 \pm 0.07^{\mathrm{a}}$ & $0.19 \pm 0.59^{\mathrm{e}}$ & $0.38 \pm 0.05^{\mathrm{e}}$ & $0.78 \pm 0.05^{\mathrm{e}}$ \\
\hline \multirow{5}{*}{ Amaranthus cruentus } & Control & $0.53 \pm 0.08^{\mathrm{a}}$ & $1.08 \pm 0.10^{\mathrm{a}}$ & $1.98 \pm 0.21^{\mathrm{a}}$ & $2.48 \pm 0.28^{a}$ \\
\hline & $20 \mathrm{~g}$ & $0.40 \pm 0.16^{\mathrm{ab}}$ & $0.87 \pm 0.25^{\mathrm{ab}}$ & $1.53 \pm 0.48^{\mathrm{a}}$ & $2.13 \pm 0.58^{\mathrm{a}}$ \\
\hline & $40 \mathrm{~g}$ & $0.40 \pm 0.10^{\mathrm{ab}}$ & $0.90 \pm 0.22^{\mathrm{ab}}$ & $1.63 \pm 0.39^{a}$ & $2.17 \pm 0.47^{\mathrm{a}}$ \\
\hline & $60 \mathrm{~g}$ & $0.38 \pm 1.50^{\mathrm{b}}$ & $0.82 \pm 0.29^{b}$ & $1.55 \pm 0.52^{\mathrm{a}}$ & $2.07 \pm 0.63^{a}$ \\
\hline & $80 \mathrm{~g}$ & $0.25 \pm 0.03^{\mathrm{b}}$ & $0.52 \pm 0.08^{c}$ & $0.88 \pm 0.01^{\mathrm{b}}$ & $1.23 \pm 0.25^{\mathrm{b}}$ \\
\hline \multirow{5}{*}{ Amaranthush ypochondriacus } & Control & $1.20 \pm 0.09^{\mathrm{a}}$ & $1.68 \pm 0.16^{\mathrm{a}}$ & $2.15 \pm 0.19^{\mathrm{a}}$ & $2.65 \pm 0.19^{a}$ \\
\hline & $20 \mathrm{~g}$ & $1.10 \pm 0.15^{\mathrm{a}}$ & $1.45 \pm 0.14^{\mathrm{b}}$ & $1.73 \pm 0.14^{\mathrm{b}}$ & $2.13 \pm 0.58^{\mathrm{a}}$ \\
\hline & $40 \mathrm{~g}$ & $0.59 \pm 0.22^{\mathrm{b}}$ & $0.93 \pm 0.20^{c}$ & $1.13 \pm 0.19^{c}$ & $1.42 \pm 0.20^{\mathrm{b}}$ \\
\hline & $60 \mathrm{~g}$ & $0.36 \pm 0.04^{c}$ & $0.45 \pm 0.05^{\mathrm{d}}$ & $0.61 \pm 0.05^{\mathrm{d}}$ & $0.71 \pm 0.08^{c}$ \\
\hline & $80 \mathrm{~g}$ & $0.26 \pm 0.04^{c}$ & $0.41 \pm 0.09^{\mathrm{d}}$ & $0.56 \pm 0.09^{\mathrm{d}}$ & $1.23 \pm 0.09^{\mathrm{b}}$ \\
\hline
\end{tabular}

Means within the column followed by the same letters are not significantly different at $\mathrm{p}<0.05$.

(1992) who found that the percentage of germination, plumule and radicle length of rice and cowpea decreased with increasing concentration of Acacia auriculiformis leaf leachates. Several reports addressed the importance of allelopathic effect of various trees $E$. camaldulensis, Prosopis julifera and Acacia nilotica which significantly affected seed germination and seed seedling growth of specific crops and weed species (Khan et al., 2004).

For Celosia argentea, control treatments were significantly higher than other treatments, for all the growth parameters studied, at different intervals under experiment, except for treatment $40 \mathrm{~g}$ at 4 WAT (Tables 1-4). Gulzar and Siddiqui (2014) reported that the allelopathic effect from aqueous extracts of $E$. alba showed an inhibitory effect on seed germination and seedling growth of weed (Cassia tora L., Cassia sophera L.) and crop plants (P. aureus L., Oryza sativa L). Amaranthuscruentus response was similar to that of Celosia argentea except for $20 \mathrm{~g}$ and $40 \mathrm{~g}$ treatments, which were not different than control treatments with respect to leaf number and plant height at $\mathrm{p}<0.05$ (Tables 1 and 2). With respect to stem girth and leaf area, Amaranthus cruentus response was not significantly different than the control at $p<0.05$ (Tables 3 and 4).

Foliar leachates have been regarded to be most phytotoxic in nature (Ferguson et al., 2013; Xuan et al., 2004). This is applicable also to $V$.paradoxa leafs, which may have contributed to the inhibitory effect on the studied vegetables. From similar experiments, researchers concluded that allelopathy and stress interact under natural condition. Romeo and Weidenhamer (1998) reported that under laboratory condition, which is less typically and therefore less stressful than field condition, the allelopathic effect might be reduced. Nevertheless, for the hereby study, biotic stress might be partially responsible for the increase of the allelopathic effect of $V$. paradoxa extract, since the experiment was carried out on the field.

Phenolic acids have been shown to be toxic to germination and plant growth processes (Einhelling, 1995). V. paradoxa contains palmitic, oleic, linoleic, arachidic, stearic and phenolics. From its composition, phenolic compounds present might be responsible for the inhibitory effect on the studied vegetables.

\section{Conclusions}

The results obtained from the current study showed that Vitellaria paradoxa has allelopathic impact on the studied vegetables, therefore $V$. paradoxa could be used as weed control. Hence, further research should be effected on the allelopathic potential of $V$. paradoxa for the natural control of weeds considering sustainable agriculture and achieving the aim of environmental welfare. 


\section{References}

Alagesaboopathi C (2011). Antimicrobial potential and phytochemical screening of Andrographis affinis Nees- an endemic medicinal plant from India. International Journal of Pharmacy and Pharmaceutical Sciences 3(2):157-159.

Ashrafi ZY, Sadeghi S, Alizade HM, Mashhadi HR, Mohamadi ER (2009). Study of bioassay the allelopathical effect of Neem (Azadirachta indica) $\mathrm{n}$-hexane, acetone and water-soluble extracts on six weeds. International Journal of Biology 1(1):71.

Babu CM, Kandasanmy OS (1997). Allelopathic effects of Eucalyptus globules Labill.

Cruz-Ortega R, Ayala-Cordero G, Anaya AL (2002). Allelochemical stress produced by the aqueous leachate of Callicarpa acuminata: effects on roots of bean, maize, and tomato. Physiologia Plantarum 116(1):20-27.

Dhawan SR, Gupta SK (1996). Allelopathic potential of various leachate combinations towards SG and ESG of Parthenium hysterophorus Linn. World Weeds 3(3-4):135-144.

Einhelling FA (1995). Mechanism of action of allelochemical in allelopathy. In: Allelopathy Organism, Processes and Application. American Chemical Society, Washington, USA pp 96-116.

Ferguson JJ, Rathinasabapathi B, Chase AC (2013). Allelopathy: how plants suppress other plants. University of Florida.

Gulzar A, Siddiqui MB (2014). Allelopathic effect of aqueous extracts of different part of Eclipta alba (L.) Hassk. on some crop and weed plants. Journal of Agricultural Extension and Rural Development 6(1): 55-60.

Harper LL (1977). Population biology of plants. London, Academic Press pp 273-278.

Jadhar BB, Gayanar DG (1992). Allelopathic effects of Acacia auriculiformis on germination of rice and cowpea. Indian Journal of Plant Physiology 35:86.

Khan MA, Marwat KB, Hassan Z (2004). Allelopathic potential of some multipurpose trees species (MPTS) on the wheat and some of its associate's weeds. International Journal of Biology and Biotechnology 1(3): 275-278.

Liebman M, Ohno T (1997). Crop rotation and legume residue effects on weed emergence and growth: applications for weed management. In: Hatfield JL(Ed), Integrated Weed and Soil Management. Ann Arbor Press, Chelsea pp 181-221.

Maranz S, Wiesman Z, Bisgaard J, Bianchi G (2004). Germplasm resources of Vitellaria paradoxa based on variations in fat composition across the species distribution range. Agroforestry Systems (in Cooperation with ICRAF) pp 60-71.

May FE, Ash JE (1990). An assessment of the allelopathic potential of Eucalyptus. Australian Journal of Botany (38):245-254.

Pearcy RW, Schulze ED, Zimmermann R (1989). Measurement of transpiration and leaf conductance. Plant Physiological Ecology. Springer Netherlands pp 137-160.

Romeo JT, Weidenhamer JD (1998). Bioassays for allelopathy in terrestrial plants. In: Haynes KF, Millar JG (Eds). Methods in chemical ecology, Vol ll. Chapman \& Hall pp 179-211.

Xuan TD, Shinjichi T, Hong NH, Khan TD, Min CI (2004). Assessment of phytotoxic action of Ageratum conyzoides L. (billy goat weed) on weeds. Crop Protection 23(10):915-922.

Zoheir YA, Aptin R, Sedigheh S, Hassan MA, Mashhadi HR (2008). Study of the allelopathic potential of Azadiracta indica (Neem). Journal of Biological Sciences 8(3):57-61. 